\title{
PENYAKIT MENULAR \\ DAN COVID-19
}

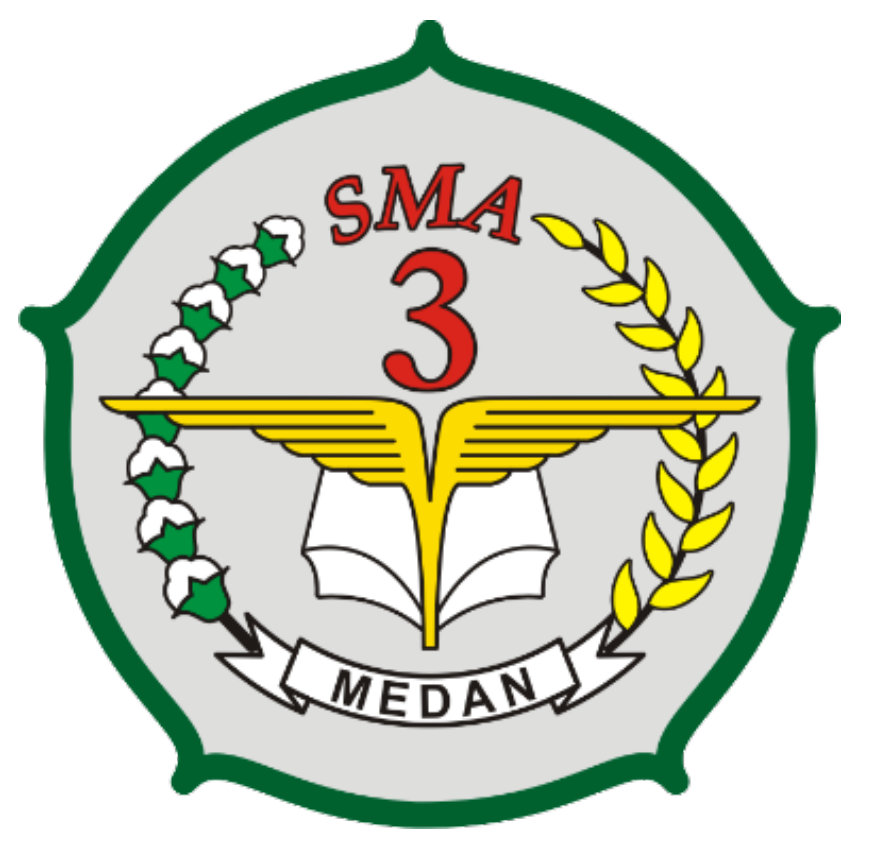

\section{DISUSUN OLEH :}

\author{
ARYA DANU HARTONO \\ X MIA 4
}

T.A 2019/2020 


\section{KATA PENGANTAR}

Assalamu'alaikum warahmatullahi wabarakatuh,

Segala puji bagi Allah SWT yang telah memberikan kami kemudahan sehingga kami dapat menyelesaikan makalah ini dengan tepat waktu. Tanpa pertolongan-Nya tentunya kami tidak akan sanggup untuk menyelesaikan makalah ini dengan baik. Shalawat serta salam semoga terlimpah curahkan kepada baginda tercinta kita yaitu Nabi Muhammad SAW yang kita nantinatikan syafa'atnya di akhirat nanti.

Penulis mengucapkan syukur kepada Allah SWT atas limpahan nikmat sehat-Nya, baik itu berupa sehat fisik maupun akal pikiran, sehingga penulis mampu untuk menyelesaikan pembuatan makalah sebagai tugas dari mata pelajaran PENJASORKES dengan judul " penyakit menular dan covid-19".

Penulis tentu menyadari bahwa makalah ini masih jauh dari kata sempurna dan masih banyak terdapat kesalahan serta kekurangan di dalamnya.Untuk itu, penulis mengharapkan kritik serta saran dari pembaca untuk makalah ini, supaya makalah ini nantinya dapat menjadi makalah yang lebih baik lagi.Kemudian apabila terdapat banyak kesalahan pada makalah ini penulis mohon maaf yang sebesar-besarnya.

Penulis juga mengucapkan terima kasih kepada semua pihak khususnya kepada guru Bahasa Indonesia kami yang telah membimbing dalam menulis makalah ini.

Demikian, semoga makalah ini dapat bermanfaat.Terima kasih.

Medan, 9 Mei 2020 


\section{KATA PENGANTAR}

\section{DAFTAR ISI}

\section{BAB I PENDAHULUAN}
A. Latar Belakang
B. Identifikasi Masalah
C. Batasan Masalah
D. Rumusan Masalah
E. Tujuan Masalah

\section{BAB II PEMBAHASAN}
A. Definisi Penyakit Menular
B. Jenis - Jenis Penyakit Menular
C. Covid-19
D. Munculnya Covid-19
E. Penyebaran Covid-19 ke Penjuru Dunia
F. Penyebaran Covid-19 di Indonesia

\section{BAB III PENUTUP}
A. Kesimpulan
B. Saran

\section{DAFTAR PUSTAKA}




\section{BAB I}

\section{PENDAHULUAN}

\section{A. LATAR BELAKANG}

Di dunia ini, manusia bisa mengidap macam-macam penyakit yang menyerang tubuh. Macam-macam penyakit yang terjadi pada manusia juga berasal dari faktor yang berbeda. Manusia dapat terserang penyakit karena tertular, atau akibat bakteri hingga virus, bahkan karena faktor keturunan.

Penyakit menular menurut para ahli adalah sebuah penyakit yang dapat berpindah dari satu orang ke orang lain. Hal tersebut disebut dengan penularan yang bisa terjadi secara langsung atau tidak langsung dan juga bisa menular melalui perantara atau penghubung. Penyakit menular biasanya ditandai dengan adanya penyebab penyakit yang hidup dan bisa berpindah menyerang inang (penderita). Penyakit menular bisa berpindah pindah dari satu orang ke orang lain. Proses penularan inilah yang harus kita cegah. Untuk bisa mencegah penularannya tentu kita harus mengetahui apa saja media yang bisa menjadi perantara cikal bakal penyakit itu. Jika sudah tahu, barulah kita menghindarinya.

Dan di antara penyakit menular tersebut termasuk jugalah penyakit yang sangat dikenali oleh orang saat ini yaitu COVID-19 atau Corona Virus Disease 2019 yang disebabkan oleh kelompok virus coronavirus. Coronavirus adalah kumpulan virus yang bisa menginfeksi sistem pernapasan. Pada banyak kasus, virus ini hanya menyebabkan infeksi pernapasan ringan, seperti flu. Namun, virus ini juga bisa menyebabkan infeksi pernapasan berat, seperti infeksi paru-paru (pneumonia).

Infeksi virus COVID-19 pertama kali ditemukan di kota Wuhan, China pada akhir Desember 2019. Virus ini menular dengan sangat cepat dan telah menyebar ke hampir semua negara, termasuk Indonesia, hanya dalam waktu beberapa bulan.

Pandemi ini juga menyebabkan gangguan sosioekonomi global,penundaan atau pembatalan acara olahraga dan budaya,dan kekhawatiran luas tentang kekurangan persediaan barang yang mendorong pembelian panik, dan tidak hanya itu. Misinformasi dan teori konspirasi tentang virus-pun telah menyebar secara daring, dan terjadinya insiden xenophobia dan rasisme terhadap orang Tiongkok dan orang-orang Asia Timur dan Tenggara. 


\section{B. IDENTIFIKASI MASALAH}

Berdasarkan latar belakang di atas masalah yang dapat diidentifikasi adalah, masih banyaknya orang yang belum memahami betul mengenai penyakit menular dimana masih ada orang yang kurang memahami tentang penyebaran penyakit menyebar ini dan pandemi COVID-19 terutama dengan adanya misinformasi lewat daring, xenophobia, ataupun rasisme dan lain lainnya.

\section{BATASAN MASALAH}

Dalam makalah ini, penulis hanya akan membahas mengenai pengertian, jenis jenis penyakit menular yang sering diderita oleh orang Indonesia, asal usul COVID-19, proses penyebaran COVID-19 di penjuru dunia, dan di Indonesia.

\section{RUMUSAN MASALAH}

1) Apa itu Penyakit Menular?

2) Apa saja Jenis jenis dari Penyakit Menular?

3) Bagaimana asal usul munculnya penyakit virus COVID-19?

4) Bagaimana proses menyebarnya COVID-19 ke penjuru dunia?

5) Bagaimana proses menyebarnya COVID-19 di Indonesia?

\section{E. TUJUAN MASALAH}

Tujuan disusunnya Makalah ini yaitu untuk:

1) Untuk mengetahui pengertian dari Penyakit Menular

2) Untuk mengetahui jenis jenis dari Penyakit Menular

3) Untuk mengetahui asal usul munculnya penyakit virus COVID-19

4) Untuk mengetahui proses menyebarnya COVID-19 ke penjuru dunia

5) Untuk mengetahui proses menyebarnya COVID-19 di Indonesia 


\section{BAB II}

\section{PEMBAHASAN}

\section{A. DEFINISI PENYAKIT MENULAR}

Penyakit menular (bahasa Inggris: transmissible disease, communicable disease, atau contagious disease) adalah penyakit yang dapat berpindah dari satu individu ke individu lain, baik pada manusia maupun hewan. Penyakit menular disebabkan oleh agen biologi seperti mikroorganisme patogenik (virus, bakteri, dan fungi) serta parasit. Keberadaan mereka di dalam atau di permukaan tubuh dapat mengakibatkan infeksi atau infestasi. Perpindahan agen infeksi atau parasit tersebut dari individu yang sakit ke individu yang sehat dapat menyebabkan menularnya penyakit.

\section{B. JENIS - JENIS PENYAKIT MENULAR}

Penyakit menular adalah penyakit yang dapat ditularkan atau berpindah dari orang yang sakit ke orang yang sehat atau belum terkena penyakit menular tersebut. Penularan penyakit tersebut dapat terjadi baik melalui perantara maupun secara langsung.

Berikut ini beberapa daftar penyakit menular yang dapat kami rangkum untuk anda :

\section{Influenza}

Influenza atau yang lebih umum dikenal dengan flu adalah penyakit menular yang paling umum diderita oleh orang-orang. Influenza ini disebabkan oleh virus. Virus influenza adalah virus yang setiap waktunya bermutasi, sehingga sistem imunitas tubuh sulit mendeteksi virus yang satu ini. Karena sulitnya sistem imun tubuh mendeteksi virus influenza ini, maka tubuh cenderung lebih mudah terkena flu. Bahkan tubuh dapat beberapa kali terkena flu dalam waktu yang berdekatan.

\section{Penularan :}

Flu dapat ditularkan melalui sistem pernapasan juga melalui air ludah. Maka jika kita berdekatan dengan orang yang sedang flu, kemungkinan kita tertular flu sangatlah besar. Perantara udara adalah media penularan flu yang paling cepat.

\section{Cara Pencegahan :}

Menjaga daya tahan tubuh agar tidak mudah terserang virus. Misalnya dengan makan teratur, istirahat yang cukup, minum air putih sesuai kebutuhan, berolah raga, dan memiliki gaya hidup yang sehat.Selain itu, menjaga daya tahan tubuh juga dapat juga didukung dengan 
asupan vitamin terutama Vitamin $\mathrm{C}$ yang bisa didapatkan di buah-buahan maupun vitamin yang dijual di toko-toko.

Pencegahan lainnya adalah dengan menggunakan masker ditempat umum, terutama bagi yang menderita influenza.

\section{Tuberkulosis (TBC)}

Tuberkulosis adalah penyakit infeksi saluran pernapasan yang disebabkan oleh bakteri basil. Bakteri basil yang menginfeksi adalah bakteri basil yang sangat kuat. Akibtanya, akan membutuhkan waktu yang lama untuk mengobati penyakit ini. Bakteri ini 90\% cenderung menginfeksi paru-paru jika dibandingkan dengan organ-organ lainnya pada tubuh manusia. Penyakit ini biasanya ditandai dengan batuk terus menerus.

\section{Penularan :}

$\mathrm{TBC}$ adalah penyakit yang menyerang pernapasan. Maka penularannya pun melalui pernapasan. Berdekatan dengan penderita TBC dapat memungkinkan kita untuk tertular. Selain itu, ketika penderita TBC batuk pun, bisa jadi itu merupakan sarana penularan TBC. Selain itu, penggunaan barang pribadi secara bergantian dengan penderita TBC aktif, seperti gelas dan sendok pun dapat menjadi jembatan penularan TBC.

\section{Cara Pencegahan :}

- Mengurangi kotak dengan penderita TBC aktif. Jika akan kontak pun, gunakanlah masker untuk melindungi pernapasan kita. Serta hindari penggunaan barang pribadi yang bergantian dengan penderita TBC aktif.

- Pemberian Vaksin BCG (diberikan pada saat balita)

- Menjaga pola hidup yang baik dengan asupan makanan yang bergizi dan olah raga teratur.

\section{Muntaber}

Muntaber adalah penyakit peradangan usus yang disebabkan oleh virus, bakteri, ataupun parasit lain seperti jamur, protozoa dan cacing. Selain karena itu, muntaber juga dapat disebabkan oleh keracunan makanan atau minuman yang mengandung bakteri atau zat kimia. Bakteri yang biasanya merupakan penyebab dari muntaber adalah bakteri Escherichia Coli. Kondisi lingkungan, terutama sanitasi air yang tidak bersih merupakan salah satu faktor besar dalam penyebaran penyakit ini. 


\section{Penularan :}

- Melalui cairan dari mulut (muntah) yang tidak dibersihkan dengan baik

- Melalui sisa kotoran yang menyebar di air yang dgunakan

- Melalui saluran air. Terutama jika sanitasi air di lingkungan sekitar masih buruk.

- Lingkungan yang tidak bersih atau sedang dalam kondisi seperti banjir yang tidak memungkinkan memiliki air bersih.

\section{Cara Pencegahan :}

- Menjaga asupan makanan yang dikonsumsi secara cukup dan seimbang

- Penggunaan air bersih untuk kegiatan sehari-hari terutama air minum

- Mencuci tangan secara teratur untuk menghindari bakteri menempel pada tangan.

Terutama sebelum dan setelah makan

- Menjaga kebersihan rumah dan lingkungan sekitar

- Membuang tinja pada tempatnya dan membersihkan dengan baik

- Mencuci seluruh bahan makanan sebelum masuk proses pemasakan

- Menjaga kebersihan peralatan makan dan minum

\section{Cacar Air}

Cacar air adalah penyakit yang disebabkan oleh infeksi virus varicella zosteryang menimbulkan bintik kemerahan di kulit yang menggelembung maupun tidak, melepuh, dan terasa gatal. Masa inkubasi virus penyebab cacar ini sekitar 2-3 minggu. Biasanya awal gejala ditandai dengan naiknya suhu tubuh.

\section{Penularan :}

- Cacar air dapat menular melalui kontak langsung dengan penderita. Seperti berjabat tangan, atau bersentuhan langsung dengan gelembung bintik yang pecah.

- Cacar air juga dapat menular melalui udara. Misalnya, saat penderita cacar bernapas, bersin, atau batuk dan terhirup oleh udara ke arah kita, kita dapat tertular cacar air.

- Melalui barang pribadi penderita, seperti pakaian

\section{Cara Pencegahan :}

- Melakukan vaksinasi cacar air

- Menjaga kebersihan diri sendiri, pakaian, dan lingkungan

- Mengkonsumsi makanan bergizi

- Menghindari sumber penularan cacar air 


\section{Tifus}

Tifus adalah penyakit infeksi pada usus halus yang disebabkan oleh bakteri salmonella.Biasanya ditandai dengan demam yang suhunya naik secara bertahap hingga membuat pendeita menggigil. Biasanya demam terjadi di malam hari dan mereda, kemudian akan naik lagi di malam berikutnya. Gejala yang lain dapat berupa sakit kepala, sakit di bagian perut, denyut jantung menurun, sampai kehilangan nafsu makan.

\section{Penularan :}

- Melalui makanan yang tercemar bakteri salmonella. Ini bisa terjadi karena sumber makanan yang tidak sehat ataupun pembersihan yang tidak baik sebelum bahan makanan tersebut dimakan. Bahkan pada sebagian kasus, ada yang disebabkan menempelnya lalat pada makanan yang sebelumnya hinggap di tinja atau kotoran milik penderita tifus. Akhirnya lalat tersebut menjadi perantara penularan tifus.

- Melalui tangan dan kuku yang tidak bersih, sehingga tanpa kita sadari bakteri salmonella yang bisa saja terdapat pada tangan dan kuku kita masuk ke dalam mulut.

- Melalui air yang digunakan untuk minum atau mencuci piring dan gelas dan peralatan makan lainnya. Untuk itulah beberapa ahli mengatakan bahwa bahaya air minum isi ulang wajib diwaspadai.

- Melalui kulit. Bakteri ini dapat masuk lewat kulit yang terkoyak akibat luka. Bisa luka bekas operasi, terjauth, atau luka lainnya.

- Tifus juga dapat menular melalui lingkungan yang tidak bersih.

\section{Cara Pencegahan :}

- Memastikan kebersihan bahan makanan sebelum memasaknya

- Mencuci tangan secara teratur, terutama sebelum dan setelah makanan

- Membersihkan luka dan segera mengobatinya

- Hindari jajan di pinggir jalan yang terlihat tidak higienis

- Menjaga daya tahan tubuh.

- Memakan makanan untuk penyakit tifus.

\section{Campak}

Campak adalah penyakit menular yang disebabkan oleh virus yang termasuk ke dalam golongan paramixovirus. Campak sangat menular. Biasanya gejalanya berupa naiknya suhu tubuh, batuk, nyeri tenggorokan, nyeri otot, hingga ruam pada kulit. Gejala ini muncul sekitar 7-14 hari setelah terinfeksi virus. 


\section{Penularan :}

Campak menular melalui cairan ludah dari penderita ketika batuk ataupun bersin.

\section{Cara Pencegahan :}

Melakukan vaksinasi ketika masih usia balita.

\section{Pneumonia}

Pneumonia atau radang paru-paru adalah suatu peradangan yang disebabkan oleh bakteri, virus, maupun parasit lainnya. Peradangan terjadi pada pulmonary alveolus (alveoli) yang seharusnya bertugas untuk menyerap oksigen dari atmosfer. Akan tetapi karena terjadinya peradangan, organ ini menjadi terisi cairan sehinggapenyerapan oksigen terganggu dan menyebabkan sulit bernapas. Gejalanya dmulai dari demam, batuk, hingga mengalami kesulitan bernapas.

\section{Penularan :}

Melalui udara yang tercemar oleh bakteri, virus, atau parasit penyebab pneumonia. Begitu juga udara yang terpapar penyebab pneumonia yang berasal dari penderita.

\section{Cara Pencegahan :}

- Mengenakan masker atau pelindung pernapasan apabila dekat dengan sumber risiko penularan pneumonia.

- Menjaga daya tahan tubuh agar tetap kuat melawan semua virus atau bakteri yang masuk ke dalam tubuh.

\section{Hepatitis}

Hepatitis adalah penyakit menularyang menyerang organ hati pada manusia. Disebabkan oleh bakteri serta virus dan tidak bersihnya lingkungan sekitar, sehingga menginfeksi hati dan terjadi peradangan.

\section{Penularan :}

- Penularan melalui oral atau masuknya penyebab hepatitis ke dalam saluran pencernaan melalui makanan atau minuman.

- Melalui cairan tubuh seperti ludah.

- Melalui kulit, seperti pemakaian jarum suntik bekas, alat tattoo, atau jarum akupuntur bekas penderita.

- Pemakaian barang pribadi bersamaan, seperti pakaian, dan peralatan makan. 


\section{Cara Pencegahan :}

- Menjaga kebersihan makanan dan minuman yang masuk ke dalam tubuh.

- Hindari pertukaran cairan tubuh, seperti ludah atau transfusi darah yang belum jelas apakah telah bebas penyakit atau tidak.

- Hindari pemakaian barang pribadi bersamaan seperti pakaian, alat makan, dan sikat gigi dengan penderita hepatitis.

- Pastikan anda menggunakan jarum baru ketika melakukan transfusi darah ataupun melakukan akupuntur.

\section{Penyakit PES}

PES atau yang juga dikenal dengan Pesteurellosis, merupakan penyakit pada tikusdan hewan pengerat lainnya yang disebabkan oleh bakteri dan dapat ditularkan pada manusia. Kutu tikus adalah yang paling sering menjadi perantara dalam penularan penyakit ini. Pada manusia, PES dapat dibedakan menjadi . Yaitu PES Kelenjar Getah Bening, PES Infeksi Luas, Dan PES Pneumonik atau PES Paru-paru.

\section{Penularan :}

- Terkena gigitan kutu tikus yang sebelumnya telah menghisap darah tikus dengan penyakit PES.

- Melalui titik-titik air liur di udara dari penderita PES Paru-paru.

- Kontak langsung dengan menyentuh luka atau nanah penderita PES.

- Kontak tidak langsung dengan menyentuh permukaan tanah yang berbakteri.

- Makanan dan minuman yang tidak bersih dan tercemar bakteri.

\section{Cara Pencegahan :}

- Membersihkan lingkungan agar tidak terdapat tikus di sekitar rumah.

- Hindari kontak langsung dengan penderita PES, atau penggunaan masker dan sarung tangan jika ingin melakukan kontak langsung.

- Menjaga asupan makanan yang bebas dari bakteri.

\section{Kolera}

Kolera adalah penyakit infeksi saluran usus yang akut yang disebabkan oleh infeksi bakteri Vibrio cholerae. Bakteri dapat masuk ke saluran pencernaan melalui makanan dan minuman yang telah tercemar bakteri ini. Pada saluran usus, bakteri ini mengeluarkan racunnya sehingga tubuh mengalami diare disertai muntah yang hebat. Sebagai akibatnya, tubuh akan masuk pada tahap dehidrasi dalam waktu yang sangat cepat. 


\section{Penularan :}

- Bakteri ini berkembang biak dan menyebar melalui kotoran manusia. Ketika kotoran berisi bakteri ini mencemari sungai, maka orang-orang yang kontak langsung dengan sungai tersebut dapat tertular. Atau bisa juga melalui ikan yang hidup di sugai tersebut dan ikan itu dikonsumsi oleh manusia.

- Makanan dan minuman yang tercemar baketri.

\section{Cara Pencegahan :}

- Sanitasi lingkungan yang baik. Terutama kebersihan air yang digunakan untuk minum, mandi, mencuci pakaian, alat makan, serta bahan makanan yang akan diolah.

- Hindari memasak ikan atau kerang setengah matang.

- Jika keluarga atau kerabat dekat ada yang terinfeksi, pisahkan barang pribadi dan tempat tidur penderita agar tidak mudah menular pada anggota keluarga atau kerabat lainnya.

\section{Polio}

Penyakit yang menyerang tubuh terutama pada bagian otot dan syaraf yang dapat mengakibatkan pelemahan otot yang bersifat permanen. Akhirnya tubuh dapat mengalami kelumpuhan bahkan hingga kematian. Penyakit ini disebabkan oleh virus polio yang sangat menular.

\section{Penularan :}

- Kontak langsung dengan penderita polio.

- Secara oral melalui ludah penderita polio.

- Virus masuk melalui mulut dan hidung.

- Bepergian ke daerah yang masih banyak terjadi polio dengan sistem daya tahan tubuh yang lemah.

\section{Cara Pencegahan :}

Vaksin polio ketika masih usia anak-anak

\section{Ebola}

Penyakit yang belakangan ini menjadi perbinacangan hangat adalah penyakit yang disebabkan oleh virus mematikan dari genus ebolavirus. Gejala yang terjadi biasanya adalah demam, sakit kepala, nyeri otot, muntah, dan pada akhirnya akan mengakibatkan peradangan hati, rusaknya ginjal, serta turunnya jumlahtrombosit secara drastis. Sampai saat ini vaksin untuk ebola belum dapat ditemukan. 


\section{Penularan :}

Kontak langsung dengan penderita, atau melalui cairan tubuh.

\section{Cara Pencegahan :}

- Hindari bepergian ke daerah rawan Ebola

- Menghindari kontak langsung dengan penderita. Aplagi terkena cairan tubuhnya seperti ludah, kotoran, ataupun keringat.

- Jika terpaksa harus kontak angsung dengn penderita, gunakan pengaman tubuh seperti sarung tangan dan masker.

\section{AIDS (Acquired Immuno Deficiency Syndorme)}

AIDS adalah penyakit yang menyerang pada sel-sel darah putih yang bertugas untuk membentuk kekebalan tubuh. Akibatnya, daya tahan tubuh menjadi merosot dan sangat mudah dihinggapi berbagai macam penyakit. AIDS dapat menyebabkan kematian.

\section{Penularan :}

- Melalui hubugan seksual dengan penderita AIDS

- Melalui cairan tubuh

- Melalui transfusi darah

- Ditularkan oleh ibu yang tengah mengandung pada bayi yang dikandungnya.

\section{Cara Pencegahan :}

- Hindari kontak dengan cairan tubuh penderita AIDS, seperti sperma, air liur, air seni, darah, dan cairan tubuh penderita lainnya.

- Bagi wanita hamil, jauhkanlah diri dari oenderita AIDS, karena akan sangat berbahaya bagi dirinya dan bayi yang dikandungnya.

- Pemisahan benda-benda pribadi dengan penderita AIDS.

\section{DBD (Demam Berdarah Dengue)}

DBD adalah penyakit menular yang disebabkan oleh virus dengue yang dibawa oleh nyamuk Aedes aegeypti Betina. Gejala yang umum terjadi adalah demam tinggi pada beberapa hari, sakit pada persendian, munculnya bintik-bintik merah, turunnya trombosit secara drastis, dan bisa terjadi pendarahan.

\section{Penularan :}

Ditularkan melalui gigitan nyamuk betina Aedes aegepty betina 


\section{Cara Pencegahan :}

- Membersihkan genangan air di sekitar rumah agar terbebas dari nyamuk Aedes aegepty.

- Menutup tempat-tempat penyimpanan air.

- Menguras bak mandi minimal satu minggu sekali

- Memebersihkan pekarangan rumah dari barang-barang bekas yang berpotensi sebagai tempat perkembangan jentik nyamuk.

\section{Rabies}

Penyakit rabies adalah penyakit yang menyerang sistem syaraf pusat pada manusia maupun hewan berdarah panas. Penyakit ini disebabkan oleh virus rabies, dan ditularkan pada manusia melalui hewan (anjing, kucing, atau kera).

\section{Penularan :}

- Melalui gigitan hewan atau luka terbuka.

\section{Cara Pencegahan :}

- Menghindari gigitan hewan atau luka terbuka pada hewan.

\section{Panu}

Tidak disangka penyakit kulit yang sering dianggap ringan ini adalah penyakit menular. Panu menjadikan kulit kita memiliki bercak-bercak putih yang kadang terasa gatal.

\section{Penularan :}

- Bisa karena jamur di handuk lembab ataupun tidak menjaga kebersihan tubuh.

- Tertular dari penderita panu lain.

\section{Cara Pencegahan :}

- Menjaga kebersihan tubuh. Cara termudah adalah dengan mandi setiap hari.

- Menghindari pemakaian handuk secara bergantian.

- Menjemur handuk setelah dipakai

- Mencuci handuk minimal satu minggu sekali.

\section{Malaria}

Malaria adalah penyakit yang disebabkan oleh infeksi parasit plasmodium. Parasit ini dibawa dan disebarkan oleh nyamuk anopheles. Penderita akan mengalami demam tinggi, menggigil, nyeri bagian tubuh serta mual hingga muntah-muntah.

\section{Penularan :}

- Melalui nyamuk anopheles. 


\section{Cara Pencegahan :}

- Menghindari gigitan nyamuk dengan berbagai cara. Memakai pakaian panjang, atau menggunakan kelambu jika berada di rumah.

- Konsultasikan dahulu dengan dokter sebelum bepergian ke daerah yang marak terjadi malaria.

\section{Cacingan}

Cacingan adalah penyakit yang masih marak di Indonesia. Hal ini dapat disebabkan karena kurangnya kesadaran dalam menerapkan pola hidup sehat dan sanitasi yang buruk. Pada penderita cacingan, akan ditemukan cacing pada tubuhnya, biasanya cacing ini dapat dikeluarkan lewat buang air besar, ataupun dari mulut dan hidung.

\section{Penularan :}

- Telur cacing dapat masuk melalui kuku dan tangan yang tidak bersih

- Makanan yang ridak dibersihkan dengan baik sebelum dimasak

\section{Cara Pencegahan :}

- Mencuci tangan dengan baik setelah dan sebelum beraktifitas di luar rungan, begitu juga ketika akan makan.

- Memastikan kebersihan makanan sebelum dimasak

- Memotong kuku dan tidak membiasakan memanjangkan kuku

- Rutin membersihkan WC setiap hari

- Menjaga kebersihan diri sendiri dan lingkungan

\section{Toksoplasmosis}

Penyakit ini disebabkan oleh parasit jenis protozoa dari kelas Toxoplasmea. Infeksi parasit ini menyebabkan peradangan bada beberapa oran tubuh seperti kulit, kelenjar getah bening, jantung, paru-paru, bahkan otak dan selaput otak. Biasanya ditularkan melalui hewan seperti kucing, anjing dan hewan lainnya.

\section{Penularan :}

- Melalui tinja kucing atau kotoran hewan perantara lain yang terkontaminasi ookista toxoplasma.

- Kontak langsung kulit dengan hewanperantara yang terluka.

- Penularan dari ibu hamil kepada bayi yang masih dikandungnya.

\section{Cara Pencegahan :}

- Memasak makanan dan minuman dengan sempurna 
- Mengobati atau menghindari hewan perantara yang sakit

- Menjaga kebersihan diri sendiri dan lingkungan sekitar

\section{Disentri Hasiler}

Bakteri patogen menjadi penyebab infeksi pada usus besar dan menjadikan tubuh terkena disentri hasiler. Gejala wal biasanya demam tinggi, mual muntah, diare hebat hingga keluar lendir dan darah bersamaan dengan kotoran.

\section{Penularan :}

- Karena kuman dan bakteri patogen yang masuk ke dalam sistem pencernaan melalui mulut.

\section{Cara pencegahan :}

- Memastikan seluruh makanan yang akan dimakan bersih

- Mencuci tangan secara teratur terutama setelah beraktifitas, dan sebelum juga setelah makan

- Menjaga kebersihan diri dan lingkungan

- Memasak air minum

- Tidak menggunakan air mentah dalam masakan

\section{Tetanus}

Tetanus disebabkan oleh kuman Clostridium tetani yang menginfeksi luka yang terbuka. Biasanya menimbulkan kejang-kejang yang dapat berulang.

\section{Penularan :}

- Melalui luka yang terbuka atau terdapat benda-benda asing pada luka tersebut.

\section{Cara Pencegahan :}

- Membersihkan luka sesegera mungkin

- Mengobati luka

- Imunisasi

\section{Konjungtivitis (Penyakit Mata Merah)}

Penyakit yang menyebabkan mata memerah karena infeksi bakteri. Biasanya menyebabkan mata menjadi bengkak, terasa sakit, dan mengeluarkan kotoran dalam jumlah banyak yang biasanya berwarna kuning atau kehijauan. 


\section{Penularan :}

- Kontak langsung dengan penderita konjungtivitis. Misalnya tangan penderita dipakai mengusap matanya, lalu dipakai berjabat tangan dengan kita dan tanga kita menyentuh mata kita sendiri.

- Virus yang terbawa oleh udara. Karena itu penderita konjungtivitis ini disarankan beristirahat di rumah dan menghindari bertemu orang banyak agar tidak menulari orang lain.

\section{Cara Pencegahan :}

- Hindari kontak langsung dengan penderita kongjungtivitis

- Memelihara kesehatan mata

\section{SARS (Severe Acute Respiratory Syndrome)}

SARS adalah gangguan infeksi akut pada sistem pernapasan yang dapat menyebabkan kematian pada penderitanya.

\section{Penularan :}

- Virus ini dapat menyebar melalui udara.

\section{Cara Pencegahan :}

- Hindari berdekatan apalagi kontak langsung secara intensif dengan penderita SARS

- Pemakaian masker sebagi pelindung pernapasan

\section{Rubella}

Rubella adalah campak Jerman yang disebabkan oleh virus rubella. Umumnya penyakit ini menjangkiti anak-anak dan remaja. Gejala yang dialami penderita rubella biasanya adalah demam, iritasi ringan pada mata, hidung tersumbat, mual dan mntah, munculnya ruam di kulit yang menyebar, membengkaknya kelenjar getah bening, sertanyeri sendi.

\section{Penularan :}

- Menular melalui titik-titik air di udara yang berasal dari batuk atau bersin penderita rubella.

\section{Cara Pencegahan :}

- Hindari kontak dengan penderita rubella, terutama ibu hamil.

- Pindahkan penderita ke ruangan terpisah dari keluarga dan kerabat

- Menjaga kebersihan diri sendiri. 
25. Flu Burung (H5N1)

Penyakit menular yang disebabkan oleh virus H5N1 pernah jadi perbincangan yang hebat karena efeknya yang dahsyat menelan korban para penderitanya. Virus yang awalnya berasal dari unggas ini dapat menyerang pada manusia. Biasanya pada manusia akan menyerang pada sistem pernapasan dengan gejala awal demam, dan dapat menyebabkan kematian jika tidak ditangani.

\section{Penularan :}

- Dapat terjadi dari hewan ke hewan

- Dapat terjadi dari hewan ke manusia melalui udara

- Juga melalui kontak langsung antara manusia dan unggas yang terinfeksi

\section{Cara Pencegahan :}

- Bagi yang sering bersentuhan dengan unggas, baiknya mencuci tangan dengan disinfektan segera setelah bersentuhan dengan unggas.

- Menghindari kontak langsung dengan unggas yang terinfeksi

- Menggunakan masker dan sarung tanga sebagai pelindung jika terpaksa kontak langsung

- Imunisasi

- Memilih unggas yang sehat untuk dimasak

- Memasak daging unggas pada suhu mencapai 80 derajat celcius.

- Menjaga kebersihan diri sendiri dan lingkungan

\section{Demam Chikungunya}

Chikugunya adalah penyakit yang ditandai dengan gejala demam, nyeri pada sendi, ruam pada kulit, dan tubuh lunglai dan lemas tidak seperti biasanya. Penyakit ini disebabkan oleh gigitan nyamuk Aedes aegepty yang membawa virus dari famili Togaviridae.

\section{Penularan :}

- Penyakit ini tidak menular dari manusia ke manusia. Akan tetapi menular apabila manusia telah digigit oleh nyambuk yang membawa virus penyebab chikungunya.

\section{Cara Pencegahan :}

- Membersihkan genangan air di sekitar rumah agar terbebas dari nyamuk Aedes aegepty.

- Menutup tempat-tempat penyimpanan air.

- Menguras bak mandi minimal satu minggu sekali

- Memebersihkan pekarangan rumah dari barang-barang bekas yang berpotensi sebagai tempat perkembangan jentik nyamuk. 


\section{Leishmaniasis}

Penyakit ini disebabkan oleh protozoa Leishmania yang dapat mengganggu organ bagian dalam juga mengakibatkan luka pada kulit. Penyakit ini ditularkan melalui gigitan lalat pasir. Jika Leishmaniasis mengganggu organ dalam, akibatnya bisa sangat fatal. Biasanya organ yang terkena adalah limpa, hati, dan sumsum tulang. Sedangkat pada kulit, luka kecil yang disebabkan Leishmaniasis, dapat semakin besar dan menjadi luka terbuka.

\section{Penularan :}

- Melalui gigitan lalat pasir

- Pada kasus yang jarang ditemukan, penularan juga dapat terjadi melalui hubungan seksual dan penularan dari ibu hamil kepad bayi yang dikandungnya.

\section{Cara Pencegahan :}

- Menghindari gigitan lalat pasir

- Berhati-hati terhadap hubungan seksual dengan penderita Leishmaniasis

\section{Demam Kuning}

Demam kuning adalah penyakit sistemik akut yang disebabkan oleh virus. Virus demam kuning ini dibawa dan ditularkan oleh nyamuk, salah satunya adalah Aedes aegepty. Meskipun penyakit ini belum ditemukan di Indonesia, akan tetapi vaksin demam kuning sangat dianjurkan WHO dan Kementrian Kesehatan RI jika ingin melakukan perjalanan internasional. Biasanya penyakit ini ditemukan di daerah Afrika dan beberapa negara di Amerika Latin.

Penyakit ini dapat merusak saluran hati, ginjal, jantung dan sistem pencernaan. Gejala yang biasa terjadi adalah demam dan mual. Pada tahap berikutnya, racun akan menyebar. Penyebaran racun ini ditandai dengan warna kulit menjadi kekuningan karena kerusakan hati. Kemudian dapat berlanjut pada gagal ginjal, meningitis, kemudian menyebabkan kematian.

\section{Penularan :}

- Menular melalui nyamuk. Salah satunya adalah Aedes aegepty, meskipun masih terdapat spesies lain yang juga menjadiperantara penularan.

\section{Cara Pencegahan :}

- Melakukan vaksinasi demam kuning

- Memakai pakaian panjang dan menutupi tubuh jika bepergian ke daerah yang terdapat risiko demam kuning. 


\section{Roseola Infatum}

Penyakit ini adalah penyakit yang menyerang pada bayi atau anak-anak yang sangat muda. Penyakit ini disebabkan oleh virus dan mengakibatkan demam tinggi dan ruam pada bayi atau anak. Terkadang disertai dengan pembengkakan kelenjar getah bening.

\section{Penularan :}

- Karena penyakit ini disebabkan oleh virus, maka penyakit ini dapat menular melalui percikan air liur penderita.

\section{Cara Pencegahan :}

- Meningkatkan dan menjaga daya tahan tubuh anak dengan pemberian makanan bergizi yang cukup dan seimbang.

\section{Anthrax}

Anthrax adalah penyakit hewan yang bersifat akut dan dapat menular pada manusia. Gejala yang dialami iasnya adalah halusinasi, serta terganggunya sistem pernapasan. Selain itu anthrax juga kadang menimbulkan bisul yang apabila pecah, akan meninggalkan bekas.

\section{Penularan :}

- Menular pada manusia ketika manusia memakan daging hewan yang telah terkena penyakit anthrax.

- Selain memakan daging, kontak langsung dengan hewan berpenyakit ini pun dapat menjadikan manusia tertular.

- Terpapar tanah yang tercemar oleh bakteri

\section{Cara Pencegahan :}

- Berhati-hati dalam memilih daging yang akan dikonsumsi.

- Hindari kontak langsung dengan hewan yang berpenyakit

- Menjaga kebersihan diri dari kotoran di lingkungan sekitar

\section{Leptospirosis}

Penyakit ini adalah penyakit yang disebabkan oleh kuman leptospira yang menyerang hewan namun dapat juga menular pada manusia. Gejala awal leptospirosis sulit dibedakan dengan influenza karena mengalami hal yang mirip. Seperti demam, sakit kepala, batuk, sakit tenggorokan, dan nyeri pada sendi. Akan tetapi pada leptospirosis terkadang disertai dengan diare dan mual muntah.

Leptospirosis menjadi berbahaya apabila kuman ini menjalar ke organ lain dan merusak selaput otak, ginjal, bahkan paru-paru. 


\section{Penularan :}

- Penyakit ini menular melalui hewan yang sedang sakit. Menular ke manusia dengan cara konta $\mathrm{k}$ dengan hewan tersebut terutama air seni tikus.

\section{Cara Pencegahan :}

- Pola hidup sehat

- Mewaspadai air seni tikus maupun hewan lainnya

- Membersihkan kandang hewan peliharaan secara teratur (bila memiliki peliharaan)

Membersihkan diri ketika telah bersentuhan dengan hewan

\section{COVID-19}

Penyakit ini disebabkan oleh koronavirus jenis baru yang diberi nama SARS-CoV2.Wabah COVID-19 pertama kali dideteksi di Kota Wuhan, Provinsi Hubei, Tiongkok pada bulan Desember 2019. diduga menyebar di antara orangorang terutama melalui percikan pernapasan (droplet) yang dihasilkan selama batuk. Percikan ini juga dapat dihasilkan dari bersin dan pernapasan normal. Selain itu, virus dapat menyebar akibat menyentuh permukaan benda yang terkontaminasi dan kemudian menyentuh wajah seseorang.

Penyakit COVID-19 paling menular saat orang yang menderitanya memiliki gejala, meskipun penyebaran mungkin saja terjadi sebelum gejala muncul. Periode waktu antara paparan virus dan munculnya gejala biasanya sekitar lima hari, tetapi dapat berkisar dari dua hingga empat belas hari. Gejala umum di antaranya demam, batuk, dan sesak napas. Komplikasi dapat berupa pneumonia dan penyakit pernapasan akut berat.

Untuk saat ini, tidak ada vaksin atau pengobatan antivirus khusus untuk penyakit ini. Pengobatan primer yang diberikan berupa terapi simtomatik dan suportif. Langkah-langkah pencegahan yang direkomendasikan di antaranya mencuci tangan, menutup mulut saat batuk, menjaga jarak dari orang lain, serta pemantauan dan isolasi diri untuk orang yang mencurigai bahwa mereka terinfeksi.

\section{MUNCULNYA COVID-19}

Pandemi coronavirus 2019-2020 atau dikenal sebagai pandemi COVID-19 adalah peristiwa menyebarnya penyakit coronavirus 2019 atau COVID-19 di seluruh dunia. Penyakit ini disebabkan oleh coronavirus jenis baru yang diberi nama SARS-CoV-2.Wabah COVID19 pertama kali dideteksi di Kota Wuhan, Provinsi Hubei, Tiongkok pada bulan Desember 2019. 
Pasien nol yang diduga merupakan dalang pandemi ini adalah seorang wanita penjual udang di Pasar Grosir Makanan Laut Huanan, Wuhan berumur 57 tahun bernama Wei Guixiang. Awalnya, pada 10 Desember 2019, dia merasa demam dan tidak enak badan. Dia memeriksakan diri ke klinik terdekat. Namun, setelah memeriksakan diri, dia kembali berjualan. Saat itulah, SARS-CoV-2 menyebar. Setelah itu, beberapa orang mengalami gejala yang sama dan pada tanggal 31 Desember 2019, ada pemberitahuan mendesak di Wuhan tentang pneumonia yang tidak diketahui penyebabnya telah menyebar ke 25 orang.

\section{E. PENYEBARAN COVID-19 KE PENJURU DUNIA}

Virus ini menular dengan sangat cepat dan telah menyebar ke hampir semua negara, termasuk Indonesia, hanya dalam waktu beberapa bulan. Virus ini juga diduga menyebar di antara orang-orang terutama melalui percikan pernapasan (droplet) yang dihasilkan selama batuk. Percikan ini juga dapat dihasilkan dari bersin dan pernapasan normal. Selain itu, virus dapat menyebar akibat menyentuh permukaan benda yang terkontaminasi dan kemudian menyentuh wajah seseorang. Penyakit COVID-19 paling menular saat orang yang menderitanya memiliki gejala, meskipun penyebaran mungkin saja terjadi sebelum gejala muncul. Periode waktu antara paparan virus dan munculnya gejala biasanya sekitar lima hari, tetapi dapat berkisar dari dua hingga empat belas hari. Gejala umum di antaranya demam, batuk, dan sesak napas. Komplikasi dapat berupa pneumonia dan penyakit pernapasan akut berat.

Total kasus positif corona (Covid-19) di dunia semakin mendekati angka 4 juta pasien. Lonjakan jumlah kasus terus terjadi karena pada saat angka infeksi baru di sebagian negara menurun, di wilayah lain justru mengalami peningkatan pesat. Data Worldometers yang diperbarui per pukul 15.23 WIB, Rabu sore, 6 Mei 2020 menunjukkan total jumlah kasus positif corona di dunia hari ini sudah mencapai 3.741.276 pasien. Di antara 3,74 juta kasus positif corona di 212 negara dan sejumlah kawasan lain serta dua kapal pesiar itu, 258.511 pasien Covid-19 telah meninggal dunia. Sementara pasien Covid-19 yang telah sembuh baru sekitar 1.247.417 orang. Berdasarkan data update dari Wolrdometers, sebanyak 2.235.348 pasien Covid-19 di seluruh dunia saat ini masih berstatus dalam perawatan. Dari 2,23 juta orang tersebut, 49.243 ( 2 persen) pasien Covid-19 mengalami kondisi kritis atau gangguan serius.

Untuk saat ini, tidak ada vaksin atau pengobatan antivirus khusus untuk penyakit ini. Pengobatan primer yang diberikan berupa terapi simtomatik dan suportif. Langkah-langkah pencegahan yang direkomendasikan di antaranya mencuci tangan, menutup mulut saat batuk, 
menjaga jarak dari orang lain, serta pemantauan dan isolasi diri untuk orang yang mencurigai bahwa mereka terinfeksi. Upaya yang dapat dilakukan untuk mencegah penyebaran virus termasuk pembatasan perjalanan, karantina, pemberlakuan jam malam, penundaan dan pembatalan acara, serta penutupan fasilitas.

Upaya ini termasuk karantina Hubei, karantina nasional di Italia dan di tempat lain di Eropa, serta pemberlakuan jam malam di Tiongkok dan Korea Selatan, berbagai penutupan perbatasan negara atau pembatasan penumpang yang masuk, penapisan di bandara dan stasiun kereta,serta informasi perjalanan mengenai daerah dengan transmisi lokal. Sekolah dan universitas telah ditutup baik secara nasional atau lokal di lebih dari 124 negara dan memengaruhi lebih dari 1,2 miliar siswa.

Pandemi ini juga menyebabkan gangguan sosioekonomi global, penundaan atau pembatalan acara olahraga dan budaya,dan kekhawatiran luas tentang kekurangan persediaan barang yang mendorong pembelian panik. Misinformasi dan teori konspirasi tentang virus telah menyebar secara daring, dan telah terjadi insiden xenophobia dan rasisme terhadap orang Tiongkok dan orang-orang Asia Timur atau Asia Tenggara lainnya.

\section{F. PENYEBARAN COVID-19 DI INDONESIA}

Pada tanggal 14 Februari 2020, pasien terinfeksi virus corona berdansa dengan WNA Jepang. Pasien berusia 31 tahun ini memang bekerja sebagai guru dansa dan WNA asal Jepang ini juga merupakan teman dekatnya. Selang dua hari, yakni 16 Februari 2020 pasien terkena sakit batuk. Pasien kemudian melakukan pemeriksaan di rumah sakit terdekat. Namun, saat itu pasien langsung dibolehkan untuk kembali ke rumah atau rawat jalan. Sayang, sakit yang dideritanya tidak kunjung sembuh. Hingga pada 26 Februari 2020, pasien dirujuk lagi ke rumah sakit dan diminta untuk menjalani rawat inap. Pada saat itulah, batuk yang diderita pasien mulai disertai sesak napas.

Pada 28 Februari 2020, pasien mendapatkan telepon dari temannya yang di Malaysia. Dalam sambungan telepon tersebut, pasien mendapatkan informasi jika WNA Jepang yang merupakan temannya itu positif terinfeksi virus corona. Setelah menjalankan tahapan pemeriksaan di rumah sakit lama, pasien kemudian dikonfirmasi positif terinfeksi virus corona. Kemudian, pasien langsung dipindahkan ke Rumah Sakit Penyakit Infeksi (RSPI) Sulianti Saroso, Jakarta Utara. Sejumlah prosedur telah dilakukan pemerintah terkait penemuan kasus corona di Indonesia. Mulai dari mengisolasi rumah pasien, menjaga rumahnya hingga merawat pasien. 
Sejak kasus pertama diumumkan, angka kasus positif COVID-19 terus mengalami lonjakan. Hingga 6 Mei, telah terkonfirmasi 12.438 kasus positif COVID-19 dengan 9.226 kasus aktif, 2.327 kasus sembuh, dan 895 kasus meninggal. Sebagai tanggapan terhadap pandemi ini, beberapa wilayah telah memberlakukan pembatasan sosial berskala besar (PSBB).

Sama seperti sebelumnya, langkah-langkah pencegahan yang direkomendasikan di antaranya mencuci tangan, menutup mulut saat batuk, menjaga jarak dari orang lain, serta pemantauan dan isolasi diri untuk orang yang mencurigai bahwa mereka terinfeksi. 


\section{BAB III}

\section{PENUTUP}

\section{A. KESIMPULAN}

Penyakit menular menurut para ahli adalah sebuah penyakit yang dapat berpindah dari satu orang ke orang lain. Hal tersebut disebut dengan penularan yang bisa terjadi secara langsung atau tidak langsung dan juga bisa menular melalui perantara atau penghubung. Beberapa jenis penyakit menular yang umum diderita oleh warga Indonesia adalah Diare, Tifus, Cacar Air, Penyakit Menular Seksual (PMS), Tuberkulosis (TB), Influenza, Campak, Pneumonia,Acquired Immunodeficiency Syndrome (AIDS), Demam Berdarah Dengue (DBD), dan penyakit yang disebabkan oleh virus yang sedang marak di penjuru dunia yaitu COVID-19.

Wabah COVID-19 pertama kali dideteksi di Kota Wuhan, Provinsi Hubei, Tiongkok pada bulan Desember 2019. Virus ini menular dengan sangat cepat dan telah menyebar ke hampir semua negara, termasuk Indonesia, hanya dalam waktu beberapa bulan. Virus ini juga diduga menyebar di antara orang-orang terutama melalui percikan pernapasan (droplet) yang dihasilkan selama batuk. Upaya yang dapat dilakukan untuk mencegah penyebaran virus termasuk pembatasan perjalanan, karantina, pemberlakuan jam malam, penundaan dan pembatalan acara, serta penutupan fasilitas.

Di Indonesia, sejak kasus pertama diumumkan, angka kasus positif COVID-19 terus mengalami lonjakan. Dan langkah-langkah pencegahan yang direkomendasikan di antaranya mencuci tangan, menutup mulut saat batuk, menjaga jarak dari orang lain, serta pemantauan dan isolasi diri untuk orang yang mencurigai bahwa mereka terinfeksi.

\section{B. SARAN}

Demikian Makalah yang saya buat, semoga Makalah ini dapat bermanfaat bagi pembaca. Karena keterbatasan pengetahuan dan referensi, Saya menyadari bahwa penulisan ini jauh dari sempurna. Apabila ada saran dan kritik yang ingin disampaikan, silahkan disampaikan kepada Saya sebab saran dan kritik yang disampaikan dapat membantu agar Makalah ini dapat disusun menjadi Makalah yang lebih baik lagi di masa yang akan datang. 
DAFTAR PUSTAKA

-https://www.kompas.com/skola/read/2020/03/02/143000069/apa-itu-penyakitmenular-

?page $=$ all,

-https://jagad.id/penyakit- menular/.

-https://liputan6.com/health/read/3922482/macam-macam-penyakit-menular-dan-

carapencegahannya-sedini-mungkin.

-https://www.jpkmsuryasumirat.com/index.php/berita/artikel/107-30-jenis-penyakitmenularpenyebab-dan-pencegahannya.

-https://id.wikipedia.org/wiki/Pandemi koronavirus 2019\%E2\%80\%932020.

-https://www.alodokter.com/virus-corona. 